\title{
Legal Research and Legal Concepts: Where Form Molds Substance
}

\author{
Robert C. Berring†
}

When Christopher Columbus Langdell stated that the library was the laboratory of the law and that law books were the "stuff" of legal research he was stating a proposition that was not only descriptive but prescriptive. ${ }^{1}$ From the late nineteenth century, the development of the American legal system can be seen as a history of the development of forms of legal publication. This history poses the question whether the forms of publication have been mere vehicles for the transmission of legal knowledge, or important influences in the development of that knowledge. This Essay has two purposes. First, I will examine the suggestion that the form in which law has been conceptualized was strongly influenced by the form in which it was published. Second, I will explore the impact that current technological innovations in legal research may have on the way legal problems and legal structures will be conceptualized in the future.

SETTING

The earliest forms of modern legal research materials began to take shape in the eighteenth century. Scholars during the Age of Enlightenment sought to use critical reason to free people from irrational prejudice and influence. They searched for rational systems of expression in the sciences and eventually extended this approach to the study of law. Law was a science, a body of knowledge that had its own structure and was reducible to rational propositions. ${ }^{2}$ This perspective dates to William

$\dagger$ Professor of Law and Law Librarian, Boalt Hall School of Law, University of California, Berkeley. B.A. 1971, Harvard College; J.D. 1974, M.L.S. 1974, University of California, Berkeley. Essay.

The author thanks Kathleen Vanden Heuvel for her assistance and criticism in preparing this

1. As Langdell put it, "The Library is to us what the laboratory is to the chemist or the physicist and what the museum is to the naturalist." HaRvard LAW SchOOL Association, THE Centennial History of the Harvard Law School 1817-1917, at 97 (1918).

2. Many great text writers would agree. Each subject area was a rational system. See, e.g., 1 J. WIGMORE, A TREATISE ON THE SySTEM OF EVIDENCE IN TRIALS AT CoMmon LAW at vii (1st ed. 1904). "The particular aspiration of this Treatise is, first, to expound the Anglo-American law of Evidence as a system of reasoned principles and rules; secondly, to deal with the apparently warring mass of judicial precedents as the consistent product of these principles and rules . ..." Wigmore 
Blackstone's Commentaries, which struggled to place the common law of England into a rational narrative structure.

Blackstone's tools were the tools of his time. Influenced by Newton and Locke he developed a rational systeni, organiznig the conimon law into a sensible whole. As Daniel Boorstin has written: "Blackstone employed these ways of thinking to make the complex legal institutions of eighteenth century England appear to be a coherent and rational system." 3 Law was perceived as a "seamless web," spun into a pattern that could be detected by the careful and thoughtful researcher. Though Blackstone has been roundly excoriated by later critics for bending the data to fit his needs, his critics did not doubt his principal claim-that the common law could be logically explained and was a part of a greater system.

Before Blackstone, law books were tools of a trade, disparagingly called "plumbers' tools" by Gilmore, that existed to serve the craftsman/ lawyer. ${ }^{4}$ The civil law of Rome was the scholarly legal area; the coninion law was simple practice. ${ }^{5}$ Blackstone attacked that premise, contending that the common law was a fit area for study and was a thing of beauty and grace in its own right. ${ }^{6}$ This concept of a coherent system also relied upon natural law beliefs in the existence of ultimate and universal systems of norms. Natural law provided the assurance that there was a structure, an absolute foundation, upon which to build the rational system. Indeed, all eighteenth and nost nineteenth century legal text writers prefaced their analyses by acknowledging the underpinning of natural law, which allowed for an ultimate sanctioning authority, and lent credence and coherence to the analysis that followed. ${ }^{7}$ Once this universal truth was established by a comnientator, the primary authorities, largely in the form of case reports, could be used as indicia of the larger

foreshadows this Essay's analysis by suggesting that the goal of constructing a consistent set of precedents and principles was achievable.

3. D. BOORSTIN, THE Mysterious SCIENCE OF THE LAW 5 (1941).

4. G. Gilmore, The Ages of American Law 3 (1977). "Lawyers continued to think of themselves, as they were thought of by others, as being plumbers or repairmen. The law books were essentially plumbers' manuals. . . . Blackstone had no predecessors."

5. 1 W. BLACKSTONE, COMMENTARIES *19.

6. Id. at 5-6. "For I think it an undeniable position, that a competent knowledge of the laws of that society, in which we live, is the proper accomplishment of every gentleman and scholar; an highly useful, I had almost said essential, part of liberal and polite education." This is still true.

7. See, e.g., $1 \mathrm{~J}$. KENT, COMMENTARIES ON AMERICAN LAw *1. In discussing the nature of international law Kent says:

But it would be improper to separate this law entirely from natural jurisprudence, and not to consider it as deriving much of its force and dignity, from the same principles of right reason, same views of the nature and constitution of man, and the same sanction of Divine revelation, as those from which the science of morality is deduced.

Id. at *2. 
structure and could be analyzed and parsed as a means to mapping out the system.

The written reports of judicial decisions were the embodiment of the common law. The origin of the myth of the common law as an unwritten but determined set of norms made manifest $m$ the actions of courts is not settled, but the centrahty of the myth is apparent. ${ }^{8}$ The rejection of this idea has been a part of legal scholarship smce Bentham. ${ }^{9}$ The myth's power is demonstrated by its continued vitality; indeed, the fact that it is still being attacked is fit manifestation of its power. ${ }^{10}$ Returning to Langdell's analogy, common law decisions were the very "stuff" of law, and reading them could lead to an intuitive grasp of law's structure. Langdell's prototype casebook contained only cases. ${ }^{11}$ By the then prevalent theory, reading cases was enough to give the law student a glimpse of the law's structure. Reading cases in the proper sequence would make the underlying primciples self-evident. All of the pieces of the puzzle could be asseinbled into a coherent picture.

Enghish-language case reports date back to the Year Books. The Year Books were manuscript law reports prepared during the period 1292 to 1535 (1 Ed. 1 - 27 H. 8). ${ }^{12}$ Though scholars have never quite agreed on the exact function of the Year Books, it is clear that Year Books were collections of notes taken down concerning actions at court and that they mcluded much material we would recognize as "court reports."13 The Year Books eventually stopped, but the desire to commit judicial decisions to writing contmued.

The new form of publication was the nominative case reporter. ${ }^{14}$ Noininative case reporters were individually compiled by a meinber of the bar whio would gather notes of the courts' decisions either as recorded by himself, from other lawyers or, perhaps, from the notes of the judges. These compilations were then published as illustrations of

8. The best simple statement of the traditional view of the common law is Common Law, authored by Roscoe Pound, which can be found in IV ENCYCLOPAEDIA OF THE SOCIAL SCIENCES 50 (1931). The article also provides a useful bibliograplyy.

9. See generally J. BENTHAM, A FRAGMENT ON GOVERNMENT (1776). This book was written by the adolescent Bentham as a direct response to Blackstone's original lectures.

10. See, e.g., Kennedy, The Structure of Blackstone Commentaries, 28 Buffalo L. REv. 205, 211 (1979).

11. C. Langdell, a Selection of Cases on the law of Contracts, with REFERENCES AND CitATIONS (1871).

12. They were called Year Books because the cases were grouped by regnal year.

13. The best introduction to the Year Books can be found in F. Hicks, Materials AND Methods of Legal Research with Bibliographical MaNual 94-102 (1923).

14. Id. at 96. As Hicks describes,"The first report to be printed in succession to the Year Books was Les Comentaires, ou les Reportes, of Edmund Plowden, first published in 1571. It was, like the Year Books, written in Law French, but English translations of it were published in 1761, 1779,1792 and 1816." 
the way past matters had been adjudicated. ${ }^{15}$ Because there was no official written record of decisions of the court, these unofficial compilations were vital repositories. The doctrine of precedent, a key component of common law theory that states that legal principles once revealed in a decision by a court should be followed in similar situations in the future, made these collections valuable. Indeed, they were crucial components for building a science of the law. The early compilers quite consciously responded to this need for precedent. Although their volumes were often financial drains, they were motivated by a mix of intellectual inducement and public spiritedness rather than hope of profit. Their prefaces were often inspiring. The words of Ephraim Kirby in his first volume of Connecticut Reports speak eloquently to this point:

Hence it became obvious to everyone, that should histories of important causes be carefully taken and published, in which the whole process should appear, showing the true grounds and principles of the decision, it would in time produce a permanent system of common law. But the court being ambulatory through the state, the undertaking would be attended with considerable expense and interruption of other business, without any prospect of private advantage; therefore, no gentleman of the profession seemed willing to make so great a sacrifice: I had entered upon this business in a partial manner, for private use; which came to the knowledge of several gentlemen of distinction. I was urged to pursue it more extensively, and being persuaded that an attempt of the kind however imperfect might be made in some degree subservient to the great object, I compiled the Volume of Reports which is now presented to the public. $^{16}$

In their early form the nommative reports were disorganized and often contradictory. They made no pretense of being comprehensive or systematic and the quality and reliability of the products varied. Only the available notes were included. Some reporters used second hand sources or notes found in estates. Wallace's The Reporters ${ }^{17}$ was published to help practitioners sort out the validity and utility of the guidance offered by individual nominative volumes. There was an enormous amount of subjective, intellectual input involved in the production of even the best reporters. It was the individual case reporter who structured and perhaps significantly rewrote the text of the report. Thus, the reporter's perception and ability was the inajor contribution. The

15. A good example of this phenomenon in American legal publication is the preface to volume 1 of the United States Reports, originally entitled volume 1 Dallas (1790), where A.J. Dallas explains his methodology. None of the cases in this volume are actually from the United States Supreme Court, indicating that case collections were idiosyncratic even at this late date in the process.

16. 1 Conn. (1 Kirby) iv (1790).

17. J. Wallace, the Reporters Chronologically arranged: With Occasional Remarks upoN Their Respective Merits (T. Johnson \& J.W. Johnson 3d ed. 1855). 
volumes could be reviewed in terms of the reporter's veracity and skill. Indeed, these early nominative court reporters were reviewed in the fashion of contemporary book reviews, and one can comb the hiterature to find attacks on, and praise of, certam nominative reports. ${ }^{18}$ The intellectual coinponent of court reporting was understood. The reports of Lord Coke, for instance, were extremely influential, not because of their accuracy, but because of the reputation and raw intellectual power of the author. ${ }^{19}$ Still, the myth persisted that it was the law, rather than the opinion of the compiler, that mattered. The law was a known quantity, simply exphicated by the commentator.

The nominative form of court reporters transferred to America and began to blossom after the revolution. The federal nature of the United States legal system and the drive to carve out a distinctive jurisprudence aided in this growth. The need for a distinctive "American" cominon law as well as a general mistrust of judges led to a spate of early reporters beginning with Ephraim Kirby's 1789 Connecticut Reports. ${ }^{20}$ As early as $1803^{21}$ soine jurisdictions began to authorize official versions of the reports of decisions in reaction to the need for systeinatic coverage. ${ }^{22}$ The early "official" reports were given the imprimatur of the jurisdiction but reinained close to the nominatives in the idiosyncracy of their makeup. ${ }^{23}$ For our purposes, we need only note that the total sum of American case reports, comprising both official and nominative volumes, was still only a few hundred at the middle of the nineteenth century. ${ }^{24}$ The sheer nuinber of volumes was beginning to be daunting, but the enterprising practitioner still could read and retain the decisions pubhished in his jurisdiction. The law presented an internally coherent structure contaming timeless truths, in largely unwritten form. The part that had been reduced to written form was manageable. The very disorganization and meagerness of the reporters meant both that one had to be able to synthesize information on one's own and that this synthesis could

18. Young, A Look at American Law Reporting in the 19th Century, 68 L. LIBR. J. 294 (1975), collects a number of reviews.

19. See F. Hicks, MEN AND Books Famous In THE LAw 78 (1921).

20. Although most agree that Kirby won the race, he may have been beaten by Francis Hopkinson's Judgments in Admiralty in Pennsylvania, also published in 1789. As one commentator suggests, "Whether Ephraim Kirby's Connecticut Reports, or Francis Hopkinson's Judgments in Admiralty in Pennsylvania, both published in 1789, was the first volume of reports to be published in America has been a source of academic debate for several geuerations, and is yet to be resolved." Surrency, Law Reports in the United States, 25 AM. J. LEgAL HIST. 48, 53 (1981).

21. See F. Hicks, supra note 13 , at $110,117$.

22. For an interesting institutional history of court reporting of the early United States Supreme Court see Joyce, The Rise of the Supreme Court Reporter: An Institutional Perspective on Marshall Court Ascendency, 83 MICH. L. Rev. 1291 (1985). Professor Joyce tells us that without the efforts of the early reporters the Marshall Court could never have reached its power so quickly.

23. See, e.g., 1 U.S. (1 Dall.) (1790).

24. See F. Hicks, supra note 13. In 1848 there were 800 volumes of law reports. 
be accomplished. Many of the persistent popular impressions of lawyers as masters of memory and logic sprang from this period. ${ }^{25}$ The growth in legal activity signaled the end of this era, but not its extinction in our collective mythology.

One long-term effect of the growth of official reports was the gradual abandonment of the nominative report's features. As time passed the character of the reporting process changed. Though the evolution followed different patterns in different jurisdictions, in general the early sparks of creativity died out. The court reporter was no longer a publicspirited volunteer; he was a state-appointed functionary. ${ }^{26}$ The occasionally chaotic and always subjective form of the early reporters was replaced by mere disorgamization as the reporter's post became a political sinecure in many states. Production was erratic and quality variable. ${ }^{27}$ Even so, official reports had some innovations that were of lasting use. The official reporters introduced a standard numbering pattern for volumes. $^{28}$ Because it was common for the courts in a jurisdiction to require citation to the official report, the official sets quickly became definitive. Statutes that created the office of jurisdictional court reporter often included provisions that required courts to deposit copies of all written decisions with the reporter; this allowed for comprehensive reporting. ${ }^{29}$

Although official sets met the need for systematic production, they failed to meet lawyers' varied and growing needs as legal activity expanded rapidly during mid-nineteenth-century industrialization. The explosion of legal activity created a need for better tools, or at the very least, established a growing market for them. The old, inefficient process was founded on assumptions from another age and could not respond to the wild growth in legal materials.

The pressures of expanding legal activity led to the development of commercial reporting. Although the story of the West Company and its

25. For an interesting commentary outside the legal literature, see N. POSTMAN, AMUSING OURSELVES TO DEATH 57 (1985) Postman explains the 19th century perception of lawyers: "A lawyer needed to be a writing and reading man par excellence, for reason was the principal authority upon which legal questions were to be decided." Id.

26. See CAL. Gov'T CODE $\S 68900$ (West 1976) for an example of a statute creating the office of court reporter.

27. For an example of erratic and delayed publication, see INDIANA CourT of APPEALS REPORTS. Indiana finally managed to get volume 182 (1979) printed in 1984.

28. Many of the sets incorporated certain nominatives as early volumes in the official numbering. This accounts for the "nominative" portion of early United States Supreme Court reports. In other states, completely private volumes were included in the sets; eventually the reporters' names were forgotten.

29. In California, CAL. PoL. CODE $\$ \$ 767-781$ (1872) established California's official reports and set out the requirements for publication. Section 780 states that "The Reporter must as soon as it is published deliver to the Secretary of State the whole of the edition." 
meteoric rise has been told elsewhere, ${ }^{30}$ it is important to note here that what made the West Company dominant as a publisher of legal decisions was its standardization of court reports and its comprehensive reporting. The significance of standardization operated on several levels. The first simply was accuracy. From the beginning, West strove to make its reporters accurate. Part of this involved getting copies of opimons. The West Company estabhished a system for receiving copies of opimions from every jurisdiction. It prided itself on gathering decisions and verifying the text with the judge who wrote them. Secondly, West established a uniform format for reporting. All West reporters were designed according to the same formula. West produced a sterile court reporting system that guaranteed rehability through similarity. Caption, syllabus, and headnotes appeared in the same form in all jurisdictions. They were produced by a centralized staff and were drafted to fit into the pre-existing structure. Although previous digests and abridgments presented and described cases, the West digests created a subject structure and fit all new cases into it. ${ }^{31}$ Further, West kept to a regular schedule and kept its prices low. The printed report, complete with verified text, thus became a standard product. ${ }^{32}$

There can be no doubt that the expansion of jurisdictions and the growing hitigiousness brought on by the Industrial Revolution played a major role in the growth of case law, but the West system inade it possible to publish in written form all of the decisions of courts that marched along with this trend. However, it was not necessary to follow this path. The Enghish model of selective reporting was available from competing concerns. ${ }^{33}$ This method allowed for publication of only a fraction of the available decisions with selection made under a set of predetermined criteria. While some publishers promoted this concept, it did not prevail. ${ }^{34}$

Lawyers chose the comprehensive style of reporting, preferring that all precedent be available. There can be little doubt that publication of so many decisions was an incentive for the publication of even more deci-

30. See W. Marvin, West Publishing Company: Origin, Growth, Leadership (1969); Woxland, Forever Associated with the Practice of Law, 5 LEGAL Ref. SERvices Q. 115 (Spring 1985).

31. See, e.g., F. Hicks, supra note 13, at 255-67 (discussing case and digest abridgments).

32. There have been many effects of the standardization of law reports. Consider, for example, recent litigation between West Publishing and Mead Data Central, West Publishing Co. v. Mead Data Central, Inc., 799 F.2d 1219 (8th Cir. 1986) in which West claimed copyright protection for its standardized pagination. West successfully enjoined Mead Data Central from using the page numbers from West's National Reporter System in MDC's online system, LEXIS.

33. The English still use this distinct method of court reporting. See M. PRICE, H. BITNER \& S. Bysiewicz, EfFEctive Legal Research \$§ 24.5-6 (4th ed. 1979).

34. American Law Reports (ALR) is the surviving product of this tradition. For an interesting insight on the competition between comprehensive and selective reporting, see $A$ Symposium of Law Publishers, 23 AM. L. REV. 396 (1889). 
sions. Once the pattern of comprehensiveness was established, the volume of cases published grew apace. Whether the gigantic growth in published cases was a response to an existing demand or the product of a stimulated demand is, in the end, not relevant. By the middle of the twentieth century, an enormous strncture of standardized case reporting had evolved. Far too many cases for any individual to master were now available and the subjective element of case reporting was gone. No longer could memory serve as the lawyer's main tool. A research system was growing from the cases organized into like elements and placed into a like format. Research skills were made fungible as research became a inechanical process.

\section{II \\ LEgal LITERATURE AND Legal THINKING}

Creating an enormous body of reported case law had implications for the specialized legal literature that grew from it. Tools that specialized in indexing cases, in collecting subsequent citations of cases, and in providing complete citations to reported cases all blossomed in the twentieth century. The very number of reported cases, combined with the large market of eager lawyers, was the driving force behind development of these specialized tools. Many were the most sophisticated research tools of their time. While each of these developments merits a careful examination, this essay is concerned with the impact that these specialized structures had on the way legal researchers conceptualized the law.

So long as the reporting of decisions was limited to those cases selected by members of the bar for their particular rectitude and value as examples, and to cases noted for their utility by a practitioner or a judge, the literature was subject to a certain quality control. In effect, the corpus of published case law was prescreened for content and precedential value. Even when the courts produced a smaller amount of business, only the truly valuable portion of that business became part of the written record. This fact, when combined with the pervasive myth of the common law as an unwritten set of immutable principles, sustained the belief in a grand scheme of legal theory. But the grand structure of law was impossible to support once the practitioner began to be bombarded witl tens of thousands of decisions. When publication standards shifted from a selection criteria of quality and utility to total comprehensiveness in coverage, the nature of legal literature changed dramatically. Now the legal researcher was confronted with enormous amounts of available and largely undigested data. The precedent that was available did not emerge from a coherent and cohesive pattern as formulated by Langdell, but instead ennerged as a large body of unorganized and contradictory principles. 
In the face of this mass confusion the myth of the grand scheme was difficult to sustain. It is hardly novel to suggest a connection between this enormous growth in the availability and production of case reports and the development of the legal realist movement. ${ }^{35}$ Naturally the growth in litigation and the simple expansion of the number of judges authoring opinions were driving forces as well. Nevertheless, the myth of a greater underlymg set of primciples might have persisted for a longer time if the selective mode of reporting had been chosen. This method would only have published those decisions chosen for their style or content. In contrast, under the comprehensive model, the publication of thousands of contradictory and unenlightened opinions undercut the theoretical basis of the common law.

The Restatement effort of the American Law Institute is one response to the disorganization and contradiction in common law decisions. ${ }^{36}$ The Restatement inovement's original goal was to provide an intelligent summary and analysis of the existing case law, distilling out the very best and discarding the dross. This codification of the common law was intended to create an edifice that wonld make it unnecessary to refer to the larger underlying body of case law. Because they intended to supersede case law, the first Restatements did not even mention case names. But such a grand plan was not fulfilled. Though cited with great frequency early on, the Restatements became another secondary source. No one stopped dipping into the mire of reported cases. Instead of replacing authority, a new authority was simply added. ${ }^{37}$ The history of the Restatement and its evolution into a persuasive secondary authority shows that the comprehensive philosophy of reporting introduced by the West Company had too deeply infected the habits and goals of American legal researchers. The new model of comprehensive reporting of all decisions, no matter how boring or stupid, was firmly im place. ${ }^{38}$

35. See, eg., L. Friedman, History of AMERican Law 282-92 (1973).

36. See Lewis, History of the American Law Institute and the First Restatement of the Law in RESTATEMENT IN THE COURTS 1 (perm. ed. 1945) for an interesting view of the Restatement movement's original purpose. Especially pertinent is the justification provided in that introduction: "Many lawyers felt that the 'growing indigestable mass of decisions' threatened the continuance of our common law system of expressing and developing law." Id. at 1. In addition, George Wickersham's original motion, which began the Restatement movement, suggested:

That we approve the formation of the American Law Institute, the object of which shall be to promote the clarification and simplification of the law and its better adaptation to social needs, to secure the better administration of justice, and to encourage and carry on scholarly and scientific legal work.

Id. at 3. These two statements make it clear that the laws of science were still believed in 1923.

37. A segment of the Shepard system is now devoted to citation of the Restatement. See SHEPARD's Restatement OF THE LAW Citations.

38. Comprehensive reporting translates into rather staggering figures: Sixty-five thousand decisions are now added annually to the National Reporter System. In addition, approxinately 65,000 memorandum decisions are reported annually. Estimate of Donna Bergsgaard, Manager Manuscript Department, West Publishing Company, telephone interview (Apr. 9, 1987). 
When taken together, the disappearance of a generally accepted natural law theory and the apparent absence of an overarching set of coherent legal principles present us with a fairly bleak picture. Twentiethcentury works such as Cardozo's Nature of the Judicial Process ${ }^{39}$ and Jerome Frank's groundbreaking Law and the Modern Mind ${ }^{40}$ were attempts to explain what judges, who obviously were not simply explicating the law, were doing. The Jurimetrics movement reflects the same intellectual endeavor. ${ }^{41}$ All ask the same question: If judges are not revealing the pre-existing timeless and colierent sclieme of the law, just what are they doing? ${ }^{42}$ It was not difficult to sliow the inconsistencies of a system that contained so many constituent parts. Where previously the mytl could be sustained on faitl, there existed too mucl empirical evidence of a very disorganized common law to continue in sucli a blindly optimistic fashion.

Yet, the whole lield against the centrifugal forces. The traditional center of law, case law, witl its common law underpinnings, continued as a part of the twentieth-century legal corpus despite the inroads of the legal reahist movennent and despite the continued deterioration of the central core of legal principle. Perhaps one reason the mytli of a colierent, underlying common law continued was the case reporting system itself. The West system included the American Digest System's classification of all cases into subjects. ${ }^{43}$ The Digest's premise is that a subject structure can be devised to encompass every possible legal problem. The original arrangement was created near the end of the nineteentli century. Called the "Key Number System," it contained four liundred main topics with thousands of subdivisions. Many of the subdivisions were layered tliree and four levels deep. Each topic and subdivision was desig-

39. B. Cardozo, The Nature of the Judicial Process (1921).

40. J. FRANK, LAW AND THE MODERN MIND (1930).

41. For a comprehensive look at the Jurimetrics movement, see Jurimetrics, 28 LAW \& Contemp. Probs. 1 (1963). The issue includes a discussion of the origins of Jurimetrics. See Loevinger, Jurimetrics: The Methodology of Legal Inquiry, 28 LAW \& CoNTEMP. Prons. 5 (1963). For an examination of the implications computers have for the definition and administration of justice, see Spengler, Machine-made Justice: Some Implications, 28 LAW \& ConTEMP. Probs. 36 (1963); see also Solomon, Jurimetrics, 8 JURIMETRICs J. 7 (1968) (discussing the application of jurimetrics in particular legal settings).

42. Ronald Dworkin has recently tackled this question. R. DwORKIN, LAw'S EMPIRE (1986). He argues that we do not have a "decent apparatus for intelligent, constructive criticism for what judges do," id. at 11, and so are unable to explain how theoretical, rather than merely semantic disagreement about law is possible. He rejects the position of the legal realists and the critical legal studies movement, which he characterizes as a theory that "there is never really law on any topic or issue, but only rhetoric judges use to dress up decisions actually dictated by ideological or class preference." Id. at 9. Instead Dworkin argues that judges, lawyers, and laymen actually develop a complex, interpretive attitude towards rules of law that can be understood by examining the structure of legal argument from an internal participant's viewpoint.

43. For a discussion of the American Digest System and its origin, see Berring, Full-Text Databases and Legal Research: Backing into the Future, 1 HIGH TECH. L.J. 27, $31-33$ (1986). 
nated a "Key Number." The idea was to provide a location within the structure for every possible legal issue. As each case was prepared for publication a West editor prepared headnotes of the decision. Each headnote represented a point of law and each headnote was assigned a Key Number. Two locations might be assigned to some headnotes, but every headnote had to have at least one.

- This subject arrangement lent its structure to American law. Because it was a universal subject thesaurus, locating every point in every case by subject, then placing the case in a location in the printed Digests, it imposed a continuing structure on the law. Language and concepts were normalized as the West editor prepared the headnotes for each case, (remeinber West pubhished a print version in its National Reporter System of every decision published), which helped to make the law comprehensible and lent overall structural coherence. Though West might adjust its subject structure, the fact of a structure remamed. Commentators criticized West, but there is no doubt that its family of publications had a profound and continuing impact on the way infornation about law was organized. West's influence may have saved the myth of the common law from what looked like its mevitable demise.

III

\section{The Current Situation}

It is commonplace among information scientists that an unindexed or misindexed piece of information is forever altered or lost. The form of presentation can be as important as the inforination itself. Thus, if cases are only available through the West Digest system, then only that intellectual structure for understandimg the interrelationships of law can prevail. In traditional legal research the major method for finding cases was the American Digest System. Like it or not, practitioners and researchers internalized the West structure, and it became the skeleton upon which the rest of the system was built. Until the mid-1970's no challenger appeared. It was at that point that computerized legal research, complete with full-text free text Boolean searching came on the scene. ${ }^{44}$ Since this system arrived, things have not been the sanie.

The history of these systeins is told elsewhere, ${ }^{45}$ but the two full-text online systems, LEXIS and WESTLAW, ended up with strikingly similar structures. Each system introduced the full text of every case into the database. "Every case" means, in large measure, every case that will be printed in a West Reporter, though both systems do mclude a few other

44. For a description of Boolean search logic, see id. at 28 n.7.

45. See id. at 38-39; see also Burson, Report from the Electronic Trenches: An Update on Computer-Assisted Legal Research, 4 Legal REFERENCE SERviCes Q. 3 (1984); Harrington, A Brief History of Computer-Assisted Legal Research, 77 L. LiBR. J. 543 (1985). 
cases. The researcher searches by specific words or word clusters occurring in the text of the decision. The items searched can be limited by any of a number of factors such as time, jurisdiction, or judge. This system represents a remarkable conceptual advance because now one can sift through the enormous mass of available cases without having to use the West subject structure. I have called this a change in the marketplace of legal information, ${ }^{46}$ but one need not be so grandiose. It may be simply the removal of the normalizing force of the West editor.

The legally trained and highly skilled West editorial staff was there to fit all cases, no matter how aberrent or strange, into the existing tradition-bound structure. Everything made sense. Everything was part of a system. Even though West was always willing to change digest headings and reorganize to meet changes in the law, the glacial pace and overwhelming comprehensiveness of the change, when made, kept the structure intact. Now the researcher can search the entire corpus of law on a word-by-word basis, free from the constraint of a subject thesaurus. Custom-designed subject structures and searches based on entirely different groupings of subjects are possible once the intervening intelligence is removed.

What effect will these new search techniques have on the way we think about the law? I do not think free-text searching signals a major breakthrough. It is instead the final step in a gradual process. The structure of legal thought has been severely strained. The legal realist movement laid down a challenge that really has never been answered. For fifty years theorists have recognized that there is no "brooding omnipresence in the sky." The old system of grand structure is gone. No serious scholar can posit a behef in the myth of Blackstone's common law. Critical Legal Studies is only the latest stage of the continumg recharacterization of the problems. Yet, the vast majority of practitioners, far from academic debates, have continued to use a research systein that imposes a structure of organization derived from the grand scheme. Perhaps this tension-between the theoretical recognition of the death of the "grand" scheme by theorists and the contmuing use of a tradition-bound subject structure by practitioners-has contributed to the odd nature of the current debate on the nature and structure of law.

The last stage is before us. We are at the point where the ability to search without an imposed structure will nakedly expose the myth of the cominon law and the beauty of the seamless web to the general legal world. There is no underlying rational structure to the law other than what the positivists give it. Allowing people to go online in free text liberates them from any requirement to fit their thoughts into a pre-existing

46. Berring, supra note 43 , at 55 . 
structure. Individual researchers are able to order legal doctrine as it suits their needs, but in doing so they inust concentrate on narrower areas of law in order to develop the expertise and sophisticated vocabulary free text searching requires. As a result, law is likely to atomize and specialize even further.

This could create a crisis in legal thinking. Perhaps it will force theoretical and jurisprudential discussions, long relegated to the world of academia, onto center stage and into the mainstream of a society that is profoundly and elementally confused about its legal system. In times of crisis it may seem comforting to reembrace the myth of a mysterious, secretive form of law, hidden in the mists; but such comfort is illusory. As new generations of lawyers find thenselves practicing law without the old conceptual constramts, they will take law into more positivist, specialized categories. This could be the signal for a new examination of the meaning of law in our society, or it could be the final stage in our deevolution into plumbers. 
